Original Research Paper

\title{
Hydrologic Modeling to Evaluate the Impact of Hydraulic Fracturing on Stream Low Flows: Challenges and Opportunities for a Simulation Study
}

\author{
${ }^{1}$ Suresh Sharma, ${ }^{2}$ Aashish Shrestha, ${ }^{3}$ Colleen E. McLean and ${ }^{4}$ Scott C. Martin \\ ${ }^{1,2}$ Civil and Environmental Engineering Program, \\ ${ }^{3}$ Geological and Environmental Sciences, \\ ${ }^{4}$ Department of Civil/Environmental and Chemical Engineering, \\ Youngstown State University, One University Plaza, Youngstown, OH 44555, USA
}

Article history

Received: 18-03-2015

Revised: 18-06-2015

Accepted: 06-07-2015

Corresponding Author:

Suresh Sharma

Civil and Environmental

Engineering Program,

Youngstown State University,

One University Plaza,

Youngstown, $\mathrm{OH} 44555$, USA

Email: ssharma06@ysu.edu

\begin{abstract}
Hydraulic fracturing (fracking) has been increasing in the eastern part of Ohio for the last few years leading to the increased stress on water resources, particularly on the hydrological low flows. Yet, evaluation of the various impacts of fracking on stream low flows using appropriate tools is still a challenging issue, even though significant progress has been achieved in recent decades to advance the scientific tools and techniques for watershed modeling. While various existing watershed models are capable of addressing water resource issues, each model is unique and the appropriate selection of model depends upon several factors. Therefore, the objective of this study are: (i) to review the current state of art for various available watershed models, including their potential capability, in order to conduct a study related to hydraulic fracking and (ii) to present a case study using best selected model application. Our review indicated that the Soil and Water Assessment Tool (SWAT) is one of the most competent models to assess water issues related to the fracking process at various spatial and temporal scales. The SWAT model incorporating hydraulic fracking is presented in a series of steps: (i) in the first step, the preparation of input data for water use and hydraulic fracking is discussed, including detail calibration and validation of the SWAT model for this study; (ii) in the second step, a case study is presented to evaluate the impact of hydraulic fracking with stream low flows by analyzing the current fracking trend in watershed; (iii) finally, issues and challenges related to data availability and sources of water withdrawal is presented. The SWAT model was calibrated and validated both for daily and monthly scales for 9 various locations of the watershed, with a monthly Nash-Sutcliffe efficiency varying from 0.49 to 0.88 for calibration and from 0.55 to 0.86 for validation. Analysis indicates that fracking practices have nominal impact on annual flows, with modest impact on seven days lows flows, especially at the localized scale, varying in the range of 5.2 to $10.6 \%$.
\end{abstract}

Keywords: Hydraulic Fracturing, Models, SWAT, Low Flow

\section{Introduction}

Recently, there has been increasing availability and use of natural gas for the transportation sector and electrical production due to technological advances with hydraulic fracturing (fracking). The production of unconventional shale gas has increased significantly to supply the growing demand for energy and support economic development (USEIA, 2011). One of the important aspects for the substantial growth of natural gas is the increased use of hydraulic fracturing. Annually, about 35,000 wells undergo some sorts of hydraulic fracturing in U.S (IOGCC, 2010). For State of Ohio, the Ohio Department of Natural Resources 
(ODNR) has projected that approximately 122 billion gallons of water will be needed if the State of Ohio drills all possible Utica wells $(20,000)$. While the fracking technology has been considered a positive aspect in term of gas production and economic development, there is a growing concern about the large amount of water needed for fracturing and possible water resources management issues. Four to six million gallons of water are commonly needed to frack a single Marcellus or Utica shale well (OEPA, 2012). The water withdrawal at such a massive scale can reduce the water level in aquifers, which may further reduce the surface water flows or deplete water storage in aquifers. Similarly, surface water withdrawal may also directly reduce the level in reservoirs, lakes and streams.

Regulatory and public agencies are also concerned about water withdrawals needed for hydraulic fracking. The impact of water withdrawal for fracking may result severe consequences; therefore, the timing, location and volume of water withdrawal for fracking are important particularly during low flow periods. Since hydraulic fracking came in practice recently, the unanticipated water withdrawal for hydraulic fracking can raise several questions about its potential impact on water resources and environment. For example, what are the possible implications on local water quality as the pollutant concentration increases due to decreased stream flows? More importantly, what are the consequences of withdrawing large amount of water from surface and groundwater resources on short and long term water availability?

In fact, there could be significant alterations in the flow system during various seasons as daily or monthly flows might significantly be reduced far below from the environmental flow limits. This may cause crisis in water supply, aquatic life and water quality, leading to the complete threat in water resources sustainability. Since oil and gas industry is one of the booming sectors over the United States and also more than 25 States of US have potential for oil and gas production, there could be a significant impact on hydrological cycle in future due to large scale oil and gas production. Therefore, there is a pressing need of a study in order to fully understand the hydrologic process at the watershed scale under the influence of fracking. For this, physically based watershed models might be appropriate tools as these models can represent 86 the physical process within watershed and capable to make an analytical study. There are various watershed models which are capable to simulate the physical and dynamic activities within watershed in order to evaluate the effect of many watershed processes and management activities on hydrologic process (Moriasi et al., 2007). For the last few decades, water resources scientists are successful to develop and advance the existing watershed models, which are operational at various temporal and spatial scales, in order to represent the various anthropogenic influence and watershed intervention in models. Watershed models, which are fully capable to represent the watershed complexity in terms of land use, soil and Digital Elevation Model (DEM), have been extensively explored to deal with water resources issues over the last few decades. However, there are limited reports or published articles which describe possible watershed models or appropriate selection of watershed models in order to simulate the watershed response under active hydraulic fracking conditions. Therefore, existing watershed models have to be carefully reviewed and their potential capabilities/limitations to conduct study related with hydraulic fracking needs to be explored. In this context, this study is unique in two ways; (i) first, it thoroughly reviews the existing watershed models with their potential capabilities and limitations, including issues and challenges in order to conduct simulation study under hydraulic fracking conditions; and (ii) second, a brief case study will be presented to explain the various processes involved for hydraulic fracking study using the selected model based on the review. While there are several opportunities of utilizing various watershed models to deal with water resources issues, we will discuss several challenges for watershed modeling and future policies 106 issues in active hydraulic fracking watershed in later part of this manuscript.

\section{Watershed Models for Hydraulic Fracking}

The lists of widely used watershed models that can be potentially applied for the evaluation of the impact of hydraulic fracking on water resources, but not limited to followings, are:

- Hydrologic Simulation Program-Fortran (HSPF) or Loading Simulation Program C++ (LSPC)

- $\quad$ Soil and Watershed Assessment Tool (SWAT)

- European Hydrological System Model (MIKE SHE)

- and Agricultural Policy/Environmental Extender (APEX)

- Watershed Risk Analysis Management Framework (WARMF)

- Hydrologic Engineering Center-Hydrologic Modeling System (HEC-HMS)

- Watershed Assessment Model (WAM)

The details of these model components and their potential capabilities to incorporate hydraulic fracking have been summarized in Table 1. These models work mostly in continuous scale with daily and sub-daily output for streamflow. In addition, these models can incorporate the addition and diversion (withdrawal) of 
the water for fracking from the various points of the watersheds (Table 1). Although all above-mentioned models are potentially capable to simulate watershed response and have their unique features, selection of appropriate model is a crucial step in order to represent hydraulic fracking for hydrologic analysis. For example, a model which is very proficient for urban area study may not be appropriate for agricultural watershed and vice versa. More importantly, model selection depends upon several factors including modeler's knowledge, understandings and technical capabilities, availability of data, time, resources, accuracy needed and purpose of the study. While the description of all the model processes and the model structure is beyond the scope of this article, the following section briefly describes and presents the major features of the existing watershed models to represent fracking for hydrologic assessment. The readers can refer various journal articles for details of the model description (Borah and Bera, 2003).

Hydrologic Simulation Program-Fortran (HSPF) (Bicknell et al., 1996) is a physically based watershed model for continuous simulation, which simulates hydrology and water quality including non-point sources and point sources. It considers simulation on pervious, impervious surface, stream channels and reservoirs, respectively for the simulation of stream flow and water quality. It is also called as parameterized intensive model as the plant growth component and tile flow component are lumped into parameters. HSPF and SWAT both can be potentially used for hydraulic fracking studies as both models have been used and compared in various watershed conditions.

Recently, several literatures were published based on the comparison between SWAT and HSPF (Singh et al., 2005; Van Liew et al., 2003; Im et al., 2003). For example, Xie and Lian (2013) compared the performance of HSPF and SWAT for hydrologic analysis in Illinois River. The authors showed that HSPF depends on the effectiveness of the calibration procedure to achieve better result and SWAT can achieve better result provided that calibration data are less. Although, HSPF can simulate better sub-daily streamflow simulation, it requires numerous parameters to characterize hydrological cycle with intensive calibration process (Im et al., 2003 and Saleh and Du, 2004). Borah and Bera (2003) reviewed both SWAT and HSPF and concluded that SWAT is a very promising model in order to conduct study on primarily agricultural watersheds and HSPF is capable for simulation in mixed agriculture and urban watersheds. Since this study is primarily focused for stream low flow conditions due to water withdrawal for fracking, SWAT could be a better choice as SWAT is considered as a better simulator on low flow (Singh et al., 2005).

Borah and Bera (2003) reviewed eleven watersheds models and found that HSPF, MIKE SHE and SWAT have strong hydrologic component applicable to watershed-scale catchments. SWAT model was also compared with fully distributed MIKE SHE and authors concluded that both models are equally competent during calibration (El-Nasr et al., 2005) while performance of MIKE SHE model was slightly better for overall prediction of stream flows.

Golmohammadi et al. (2014) evaluated three widely used hydrological distributed watershed models: MIKE SHE, APEX and SWAT for flow simulation of $52.6 \mathrm{~km}^{2}$ Canagagigue Watershed in Southern Ontario, Canada. MIKE SHE was concluded as more accurate for simulating streamflow at watershed outlet and SWAT was regarded as another potential model as the only difference with MIKE SHE was in the validation period.

A Report on Model selection, for a study in Central Oahu Watershed, sorted out few top rated watershed models including SWAT, WARMF and HSPF based on thirteen specific model capabilities. Authors reported that WARMF model was considered less established than SWAT and HSPF. Similarly, the successful applications of HEC-HMS (Verma et al., 2010) and WAM model for watershed scale studies (Bottcher et al., 2012) have been reported in several studies.

Table 1. List of watershed models possibly used for hydraulic fracking study

\begin{tabular}{|c|c|c|c|c|c|}
\hline Models & $\begin{array}{l}\text { Model inputs for } \\
\text { hydrologic analysis }\end{array}$ & $\begin{array}{l}\text { Computational } \\
\text { time scale }\end{array}$ & $\begin{array}{l}\text { Options to incorporate } \\
\text { point source/water } \\
\text { withdrawal for hydraulic } \\
\text { fracking }\end{array}$ & Internet source & Time scale \\
\hline HSPF/LSPC & $\begin{array}{l}\mathrm{DEM} / \text { landuse/soil/precipitation/ } \\
\text { temperature and climate data }\end{array}$ & Daily/Sub-hourly & Yes & $\begin{array}{l}\text { http://www.epa.gov/athens/ } \\
\text { wwqtsc/html/lspc.html }\end{array}$ & Continuous \\
\hline SWAT & $\begin{array}{l}\mathrm{DEM} / \text { landuse/soil/precipitation/ } \\
\text { temperature and climate data }\end{array}$ & Daily/hourly & Yes & http://swat.tamu.edu/ & Continuous \\
\hline MIKE-SHE & $\begin{array}{l}\mathrm{DEM} / \text { landuse/soil/precipitation/ } \\
\text { temperature and climate data }\end{array}$ & Daily/hourly & Yes & $\begin{array}{l}\text { http://www.mikepoweredbydhi.com/ } \\
\text { download/mike-by-dhi-2014 }\end{array}$ & Continuous \\
\hline APEX* & $\begin{array}{l}\mathrm{DEM} / \text { landuse/soil/precipitation/ } \\
\text { temperature and climate data }\end{array}$ & Daily & Yes & http://epicapex.tamu.edu/apex/ & Continuous \\
\hline WARMF & $\begin{array}{l}\mathrm{DEM} / \text { landuse/soil/precipitation/ } \\
\text { temperature and climate data }\end{array}$ & Daily/hourly & Yes & $\begin{array}{l}\text { http://www.epa.gov/athens/wwqtsc/ } \\
\text { html/warmf.html }\end{array}$ & Continuous \\
\hline HEC-HMS & $\begin{array}{l}\mathrm{DEM} / \text { landuse/soil/precipitation/ } \\
\text { temperature and climate data }\end{array}$ & Daily/hourly & Yes & $\begin{array}{l}\text { http://www.hec.usace.army.mil/ } \\
\text { software/hec-hms/downloads.aspx }\end{array}$ & Continuous/ \\
\hline WAM & $\begin{array}{l}\mathrm{DEM} / \text { landuse/soil/precipitation/ } \\
\text { temperature and climate data }\end{array}$ & Daily/hourly & Yes & $\begin{array}{l}\text { http://www.epa.gov/athens/wwqtsc/ } \\
\text { html/wamview.html }\end{array}$ & $\begin{array}{l}\text { event-based } \\
\text { Continuous }\end{array}$ \\
\hline
\end{tabular}


Even though we found models performance rating different for different application studies for various models, we decided to select SWAT model due to numerous reasons: (i) SWAT models has advanced in comparison to other models and can disintegrate watershed into multiple subbasins and Hydrologic Response Units (HRUs) for continuous simulation of flow at various scales (Jha, 2011); (ii) model is widely accepted worldwide by scientific community and well supported by USDA; (iii) model is also considered suitable for the ungagged watershed (USEPA, 2012) and watershed characterized with limited data. Therefore, SWAT has been widely used for the assessment of the impact of intensive water use on the water balance and its components. In addition, SWAT is user friendly and new users can successfully apply it for the analysis of various water resource problems. It has been extensively supported through various international conferences, training workshops, online swat user group forum, broad online documentation, supporting software and open source code (Gassman et al., 2014). While Mike SHE and HSPF are equally competent, SWAT model is chosen for this study based on its historical credentials, diverse application and open source code so that it can be modified for the intended purpose.

The successful model application for SWAT varies from drainage areas of 7.2 to $444,185 \mathrm{~km}^{2}$ (Douglas-Mankin et al., 2010). Several journal articles have been published on the application of this model to assess low flow conditions (Rahman et al., 2010; Stehr et al., 2008) and the potential impact of many management practices on runoff (Arabi et al., 2008). Since various publication records reveals enough evidences that SWAT can be potentially applied for wide and diverse watershed conditions (Gassman et al., 2007; 2010), this is a unique opportunity to apply this model for the assessment of impact sustained due to hydraulic fracking. A systematic approach has been presented in the following section to explore the potential of SWAT model to incorporate hydraulic fracking in the watershed for the hydrologic assessment.

\section{Overview of SWAT Model}

SWAT is a physically-based watershed model, which is developed to predict the long term impact of watershed management in terms of hydrologic and surface water quality response of large watershed (Arnold et al., 1998). SWAT simulates different physical and hydrological process across river watersheds. The model is widely used in different regions of the world and has many peer review publications (Gassman et al., 2007; 2010).

Initial input to SWAT model is geographical information such as digital elevation model to spatially delineate watershed in terms of different subwatersheds. Further, land use, soil and slope information are utilized to subdivide the subwatersheds into smaller Hydrologic Response Units (HRU's), which are composed of similar land use, soil and management characteristics.

The loss in flow is due to evapotranspiration and the transmission of flow through the bed. Potential evapotranspiration is determined by various methods such as Hargreaves method (Hargreaves and Samani, 1985), Penman-Monteith (Allen, 1986; Monteith, 1965) and Preistly-Taylor (Priestley and Taylor, 1972). SWAT consists of two components: (i) Runoff generation through the land; (ii) and movement of water using appropriate routing scheme. The readers are suggested to refer SWAT user's manual for water balance equation adopted in SWAT model.

The model estimates the surface runoff from each HRU using two infiltration methods; Soil Conservation Service's Curve Number (CN) method (USDA, 1972) or the Green and Ampt infiltration method.

Since fracking has potential to threaten the management practices in critical conditions due to the alteration of the volume and the intensity of water withdrawal both at spatial and temporal scales, SWAT model can be utilized to incorporate water withdrawal for fracking in a similar way that it has been used for other water use and withdrawal. For example, simulation of irrigation on agricultural land is performed under five sources: Reservoir, stream reach, shallow aquifer, deep aquifer and a water body out of watershed. That is, users can utilize any of these sources for providing additional water input and water withdrawal through positive and negative value, respectively. Few options for incorporating water withdrawal for hydraulic fracking are: (i) To use point sources option in SWAT model with negative value, (ii) imitate water withdrawal and irrigation scenario in the agricultural practices for fracking assessment. Alternatively, water use input as positive and negative value can be used as an option to represent water withdrawal and water discharge as sink and source in SWAT model to represent hydraulic fracking. In addition, the incorporation of GIS technology in SWAT provides ample potential for inputs and response through spatial locations of fracking operations. The simulation in SWAT can be executed for any particular desired dates and period.

While SWAT model was used within the Fayetteville Shale in Arkansas for analyzing the potential impacts of water extraction for hydraulic fracturing (Jackson et al., 2013), we are not aware of published research paper using any hydrologic models to assess the impact of hydraulic fracturing on stream 
low flows. Even though EPA has initiated to conduct a study to evaluate the impacts of fracturing on water resources using SWAT model in upper Colorado River watershed, the result has not been published yet in peer review journals.

Based on the review of existing models and their capabilities, SWAT model has been considered as one of the suitable models in order to conduct the study related with the potential impact of fresh water withdrawal for hydraulic fracking on water resources. The detailed process for development of the model, which includes watershed delineation, preparation of input files, model calibration, parameterization and validation, is described in the following section.

\section{Study Area}

The simulation study was focused in the Muskingum watershed (Fig. 1) of eastern Ohio, which is one of the most affected regions due to hydraulic fracking. Watershed covers a significant portion of Ohio State $(20 \%)$ with an approximately 8,000 square miles in area. The watershed covers some or entire portion of the 26 counties in Ohio.

Originating at the union of Tuscarawas and Walhonding River near Coshocton, Muskingum River, the largest river in the watershed, eventually drains into the Ohio River at Marietta after flowing 109 miles to the South. Some of the major sub streams of the river are Tuscarawas, Walhonding, Licking River and Wills Creek. The Watershed is a HUC-4 watershed (0504), which is subdivided into number of HUC-8 level watersheds. The maximum, minimum and average flows at the outlet of the watershed are $23,900 \mathrm{cfs}, 477 \mathrm{cfs}$ and $2,760 \mathrm{cfs}$, respectively. The average annual precipitation over the entire watershed is approximately 39 inches. The minimum elevation range in watershed from sea level is 177 and maximum up to $459 \mathrm{~m}$. Watershed is characterized with several lakes and reservoirs for water supply, recreation and flood reduction purposes. Interestingly, more than $90 \%$ (approximation) of natural gas wells in Ohio lie in this watershed (Fig. 2); most of them are concentrated in the eastern portion of the watershed.

\section{Materials and Methods}

\section{Model Input}

The current version of the SWAT model was utilized for this study. The model requires the inputs including Digital Elevation Model (DEM), land use, soil, reservoir, weather, water use, point source, groundwater and management for successful simulation of the stream flows. The data needed for model development has been presented in Table 2 with necessary source and format.

About $30 \mathrm{~m}$ resolution DEM from USGS National Elevation dataset and ARCGIS were utilized in order to delineate stream networks. The watershed was delineated with a number of subbasins (406). Since the National Land Cover Dataset (NLCD) is compatible with the SWAT model, datasets of $30 \mathrm{~m}$ resolution was utilized from NLCD database. The reason for selecting NLCD data for year 2006 is to adequately represent the land use pattern during model calibration period (2002209). The watershed land use was mainly dominated with forest (47\%) comprising both deciduous and evergreen. Other major land use categories of the watershed include agricultural land with row crops $(23 \%)$ followed by hay (19\%) and urban areas $(10 \%)$. Nearly $1 \%$ of the watershed includes industrial area, water, range grass, southwestern arid range etc. In order to adequately represent the storage effect in hydrologic analysis, the spatial location of existing major reservoirs (Table 3) were identified in the watershed and manually added at a suitable location (Fig. 1). Since the watershed is relatively larger in size, we utilized the State Soil Geographic dataset (STATSGO) (USDA, 1991), which is in-built in SWAT model. In the next step, we selected the threshold in each subbasin for landuse (5\%), soils (15\%) and slopes $(15 \%)$ in order to eliminate minor land uses and assign multiple HRU's for each sub basin; the total numbers of HRU in the watershed were 6176. Since hydrological modeling requires spatially distributed long term climate data, climate data including precipitation, maximum temperature and minimum temperature located at various spatial locations within the watershed were utilized from National Climatic Data Center (NCDC) in order to capture the spatial variability of precipitation and temperature. Only 23 precipitation stations and 19 temperature gauge stations, with continuous data record for a longer period, were located within the watershed (Fig. 1). Rest of the meteorological data including solar radiation, wind speed and relative humidity were utilized through weather generator option available in SWAT model. Daily streamflow data available from period 1993 to 2009 were downloaded at 9 USGS locations (Fig. 1) within the watershed in order to conduct multi-site model calibration and validation. Since watershed comprises number of multi-purpose reservoirs, storage effect and flood reduction due to these reservoirs should be incorporated in a model. For this, daily mean outflows from reservoir were obtained from US Army Corps of Engineers (USACE) through the personal communication. 
Major point sources data $(>0.5$ MGD) were downloaded from Ohio Environmental Protection Agency (OEPA). Similarly, water use data for various purposes including surface and ground water, irrigation, power plant, industry, mineral extraction, water supply and hydraulic fracturings were downloaded from Ohio Department of Natural Resources (ODNR). However, ODNR does not provide any withdrawal information for less than $100,000 \mathrm{gal} / \mathrm{day}$; therefore, information was additionally verified for smaller withdrawal from
OEPA in order to include all facilities especially for water supply data. The spatial locations of oil and natural gas wells and sources for freshwater, which was needed as model input were utilized from ODNR. Since, a part of water withdrawal for hydraulic fracking is recycled, we utilized the information related with recycled water, fracture data and fresh water required per well from fracfocus, the National hydraulic fracturing chemical registry. Figure 3 shows the fresh water withdrawal, part of the water recycled and the vertical depth of wells in various years in Muskingum watershed.

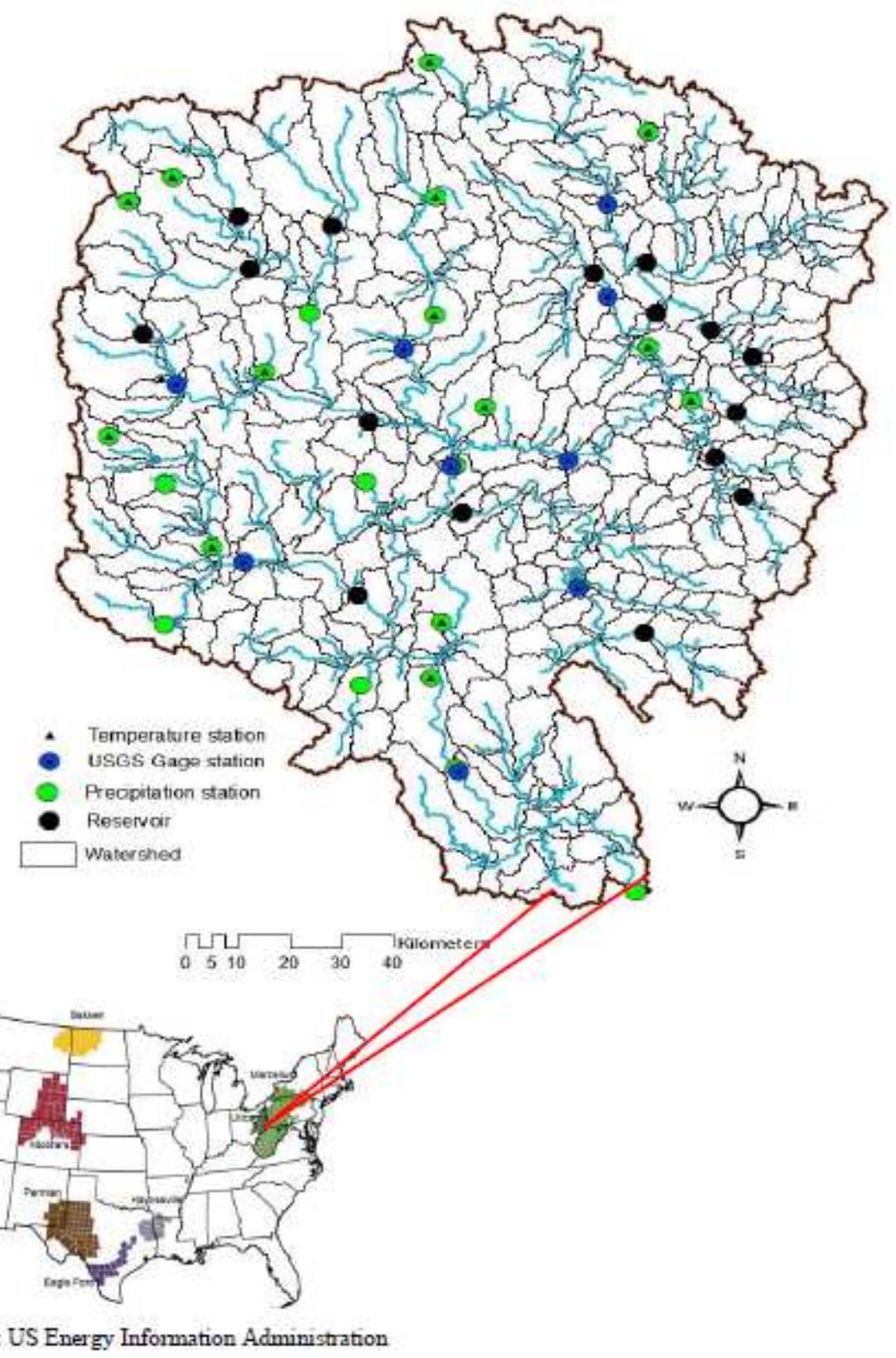

Fig. 1. Location of climate stations including reservoir and USGS gage stations in the Muskingum watershed 


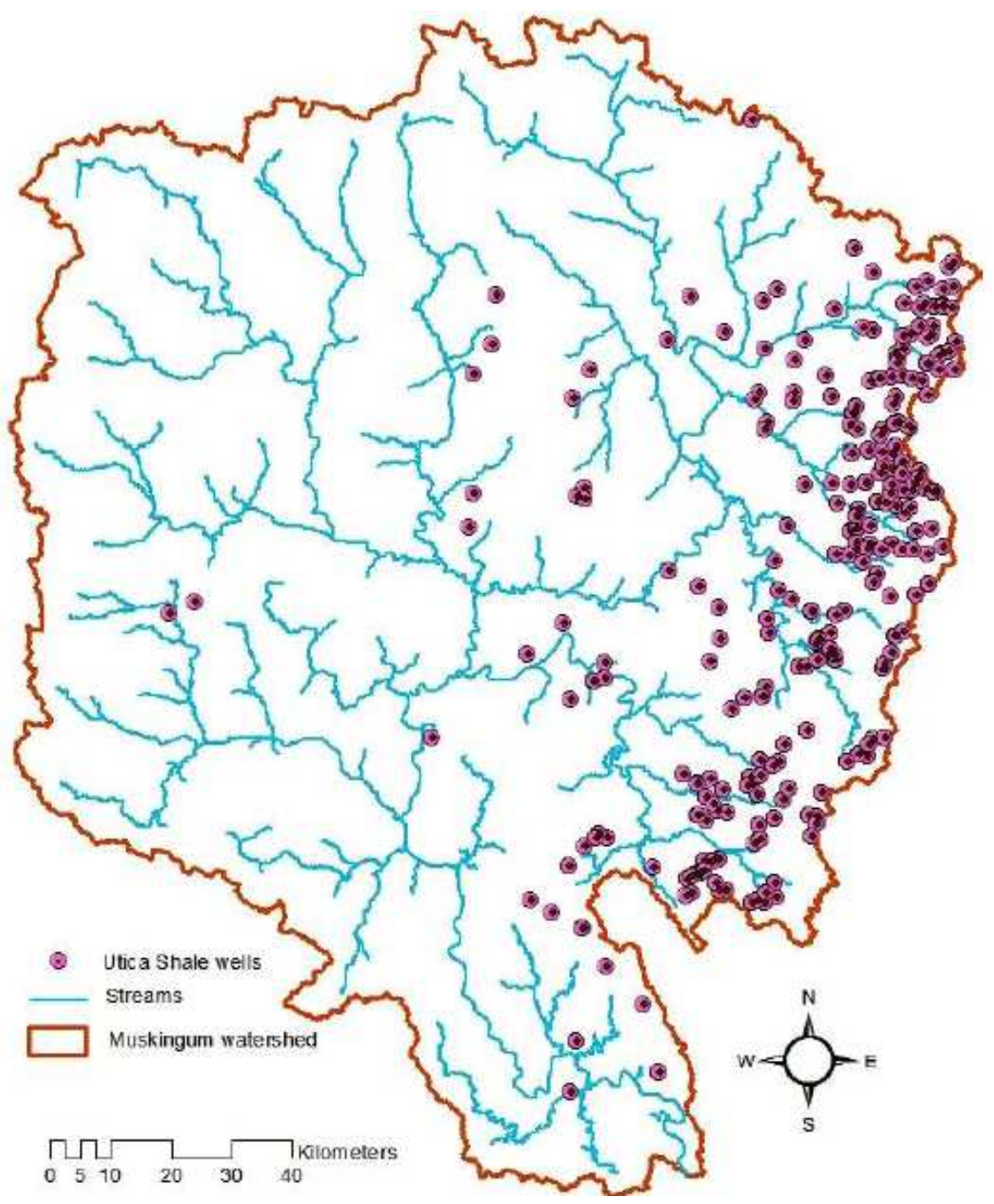

Fig. 2. Utica shale wells in Ohio

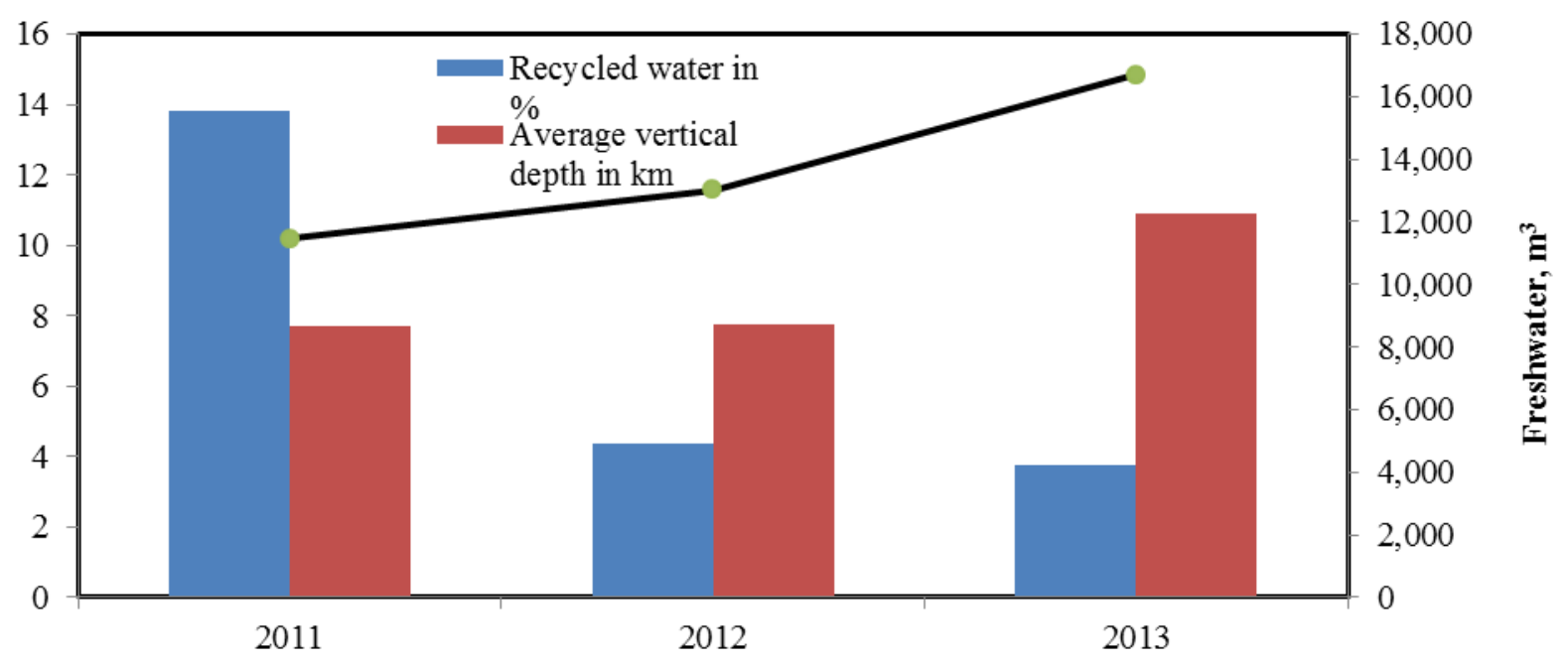

Fig. 3. Fresh water withdrawal, average vertical depth and recycled water for hydraulic fracking in Muskingum watershed in various years 
Table 2. Data and sources used for the study

\begin{tabular}{lll}
\hline Data type & Data & Source \\
\hline GIS & DEM of 30-meter resolution & USGS \\
& Land cover datasets, 2006 & NLCD \\
Climate data & Soil data & Precipitation and temperatures \\
Hydrology & Streamflows & NCDC \\
& Lake and reservoir outflow & USGS \\
Water use (Surface and ground water) & Water use for irrigation, public, power, mineral & ODNR \\
Major point sources & extraction, industries and golf course & Ohio EPA \\
Information related with hydraulic fracking & Flow discharge & Ohdraulic fracking information including sources \\
& of drilling water & Orilling water estimate per well and future drilling trend
\end{tabular}

Table 3. Major reservoirs in the Muskingum watershed

\begin{tabular}{lllc}
\hline Watershed & Reservoirs & Locations & Drainage area $\left(\mathrm{km}^{2}\right)$ \\
\hline Tuscarawas river watershed & Leesville & McGuire creek & 124.32 \\
& Atwood & Indian fork & 181.30 \\
& Tappan & Little stillwater & 183.89 \\
& Clendening & Stillwater creek & 181.30 \\
& Beach city & Sugar creek & 776.97 \\
Walhonding river watershed & Piedmont & Stillwater creek & 217.56 \\
& Charles Mill & Black fork & 559.44 \\
Will creek watershed & Pleasant Hill & Clear fork & 515.41 \\
& North Branch of Kokosing & North branch & 116.50 \\
Licking river watershed & Wills Creek & Mainstem & 1872.60 \\
& Senecaville & Seneca fork & 313.39 \\
\hline
\end{tabular}

Table 4. Model parameters used in the streamflow calibration

\begin{tabular}{llr}
\hline Parameters & Range & Calibrated value \\
\hline Surface runoff lag time & $0.5-10$ & 8.65 \\
Snowmelt base temperature & $0-10$ & 1.28 \\
Maximum melt rate for snow during year (occurs on summer solstice) & $0-10$ & 3.85 \\
Minimum melt rate for snow during the year (occurs on winter solstice) & $0-10$ & 4.38 \\
Snow pack temperature lag factor & $0-1$ & 0.71 \\
SCS runoff curve number for moisture condition II & -0.4 & 0.95 \\
Base flow alpha factor & $0-1$ & 0.72 \\
Threshold depth of water in the shallow aquifer for 'revap' to occur & $0-500$ & 119.17 \\
Groundwater delay time & $0-500$ & 254.17 \\
Groundwater revap. coefficient & $0-0.2$ & 0.19 \\
Threshold depth of water in the shallow aquifer required for return flow to occur & $0-3000$ & 585.00 \\
Soil evaporation compensation factor & $0-1$ & 0.93 \\
Soil available water storage capacity & -0.2 & -0.06 \\
Soil conductivity & -0.2 & -0.07 \\
Soil bulk density & -1.1 & 0.25 \\
Plant uptake compensation factor & $0.01-1$ & 0.90 \\
Manning's n value for overland flow & $0.01-10$ & 0.10 \\
Manning's n value for main channel & $0-0.15$ & 0.13 \\
Effective hydraulic conductivity in the main channel & -500.01 & $0-156.24$ \\
Snow water equivalent that corresponds to 50\% snow cover & $0-0.918$ & 0.62 \\
Minimum snow water content that corresponds to 100\% snow cover & $0-500$ & 130.83
\end{tabular}

\section{Model Calibration and Validation}

A hydrologic model needs to be properly calibrated and validated before conducting any scenario analysis related with watershed management. Since model calibration is a process of determining the suitable model parameters with successive iteration, SWAT-CUP (Abbaspour, 2007) was selected to calibrate the suitable model parameters using continuous flow data from 2001 to 2009. For this, SUFI-2 algorithm was utilized, which 
takes into account the possible parameters ranges and determine the optimum model parameters within the uncertainty range of $95 \%$ (Abbaspour et al., 2007). Several model parameters (Table 4) were selected in order to conduct multi-site model calibration and validation within the watershed.

Since the USGS observed flow data were available since 1993, the model was simulated for 15 years from 1995 to 2009. The model was allowed three years (1993-1995) of warm up time period before the simulation period in order to stabilize the hydrological conditions such as antecedent moisture content and base flow. The various model parameters (21) were selected based on the similar past studies (Abbaspour et al., 1999; 2007; Faramarzi et al., 2009; Schuol et al., 2008; Yang et al., 2008). The model was calibrated at 9 various locations of the watershed in a daily as well as monthly time scale using continuous data available from 2002 to 2009. The SWAT model was validated with independent datasets from period 1995 to 2001 and the performance of the model was evaluated using various statistical measures including coefficient of determination $\left(\mathrm{R}^{2}\right)$, Nash-Sutcliffe coefficient of Efficiency (NSE) (Nash and Sutcliffe, 1970) and Percent of bias (PBAIS).

\section{Model Evaluation Criteria}

Performance evaluation of the model is always a key issue for any hydrological modeling as there is not a single best statistical measure to check the performance of a model's outputs with observed data. There are three non-dimensional and one dimensional measure which are widely used to assess the model performance. These model performance measures are coefficient of determination $\left(\mathrm{R}^{2}\right)$, Nash-Sutcliffe coefficient of Efficiency (NSE) (Nash and Sutcliffe 1970), Root Mean Square Error (RMSE) and percent of bias (PBAIS), which are mathematically represented as follows:

$$
R^{2}=\frac{\left[\sum_{i=0}^{n}\left(O_{o b s, i}-\bar{O}_{o b s}\right)\left(O_{s i m, i}-\bar{O}_{s i m}\right)\right]^{2}}{\left[\sum_{i=0}^{n}\left(O_{o b s, i}-\bar{O}_{o b s}\right)^{2}\right]\left[\sum_{i=0}^{n}\left(O_{s i m, i}-\bar{O}_{s i m}\right)^{2}\right]}
$$

$\mathrm{R}^{2}$ varies from 0 to 1 which indicates the proportion of the total variances in the observed data:

$$
N S E=1-\frac{\sum_{i=1}^{n}\left(O_{s i m, i}-O_{o b s, i}\right)^{2}}{\sum_{i=1}^{n}\left(O_{o b s, i}-\bar{O}_{o b s,}\right)^{2}}
$$

NSE is a measure of how well the actual and simulated data fits and its coefficient varies from $-\infty$ to 1 . The perfect model shows the value very close to 1 :

$$
R S R=\frac{R M S E}{S T D E V_{o b s}}
$$

RMSE-observations standard deviation ratio (RSR) is also another model statistics, which standardizes RMSE with standard deviation of observed data. Ideal value of RSR is zero:

$$
P B I A S=\frac{\sum_{i=1}^{n} O_{s i m, i}-\sum_{i=1}^{n} O_{o b s, i}}{\sum_{i=1}^{n} O_{o b s, i}}=\frac{\bar{O}_{s i m, i}-O_{o b s}}{\bar{O}_{o b s}}
$$

Here, $O_{o b s, i}$ and $\mathrm{O}_{\text {sim, i }}$ are observed and simulated streamflow for each $\mathrm{i}^{\text {th }}$ observation and $\mathrm{n}$ is the number of observations. Similarly, $\bar{O}_{o b s}$ and $\bar{O}_{s i m}$ are the mean observed and simulated streamflow. PBIAS is simply an indication of the deviation of the simulated result with the observed data.

\section{Results and Discussion}

\section{Fracking and Analysis}

The calibrated and validated SWAT model was integrated with water use, point sources data and fracking condition of year 2012 in order to analyze the streamflow with given rate of fracking condition. Monthly consumptive water use was provided in model from the water use input file based on the removal of water from reach, shallow aquifer and reservoirs within subbasin. Since the continuous lake outflow data were not available, 50 percentile of the available data from USACE was applied for a period of 1995 to 2009 in order to best represent lake outflow. When this study was conducted, only the fracking data up to year 2012 were available; therefore, current period in this manuscript actually represent the conditions of year 2012.

\section{Model Simulation}

The performance of the model was evaluated through various criteria including visual inspection and goodness of fit. The performance of the model was satisfactory both in daily and monthly scale during model calibration and validation period. Figure 4 and 5 provide the box plot of daily and monthly statistical parameters including NSE, $R^{2}, R S R$ and PBIAS to measure the performance of the model. In majority of watershed locations, NSE, RSR and PBIAS were well above the minimum suggested ranges of Moriasi et al. (2007) (NSE $>0.5, R S R \leq 0.7$ and $P B I A S \pm 25 \%$ ). NSE values varied from 0.40 to 0.65 for daily streamflow calibration and it varied from 0.4 to 0.65 for streamflow validation (Fig. 4). Similarly, the NSE was obtained in the range of 0.49 to 0.89 for monthly streamflow calibration and 0.55 to 0.86 for 
monthly streamflow validation (Fig. 5). However, the validation of the model was limited to 8 USGS stations as the long term data were not available at the outlet. The nearest stations (USGS 3142000) near to the outlet also did not have a continuous record beyond 1998; therefore, validation at this station was accomplished using three years of data (Fig. 5).

Since SWAT model can relatively better simulate the monthly streamflow compared to daily streamflows, the performance of the model was relatively promising in monthly scale compared to daily scale. Performance of the model was satisfactory for all stations except at one station (USGS 03136500). The model performance at this station was

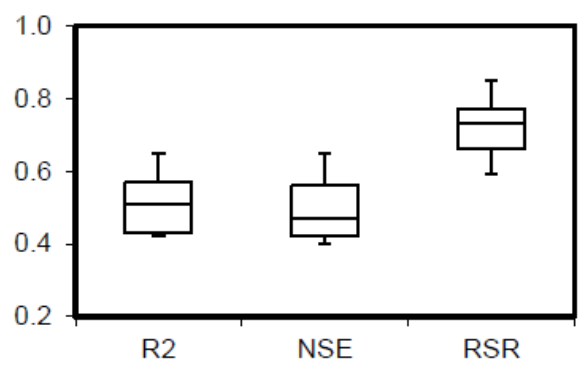

(a) affected due to lack of reservoir outflow data as this station was immediately below the reservoir. As expected in any watershed modeling, the performance of the model was relatively better in the downstream portion of the watershed as these stations covers large portion of watershed. Furthermore, the performance of the model was also assessed through the visual inspection of observed and simulated streamflow time series over a long period. The performance was found to be satisfactory during calibration (Fig. 6) and validation period (Fig. 7). Despite of the slight underestimation in daily and monthly simulated peak, the model captured the overall spatial and temporal pattern of stream flow satisfactorily.

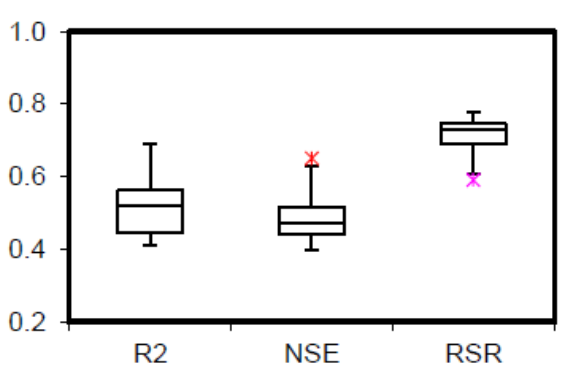

(b)

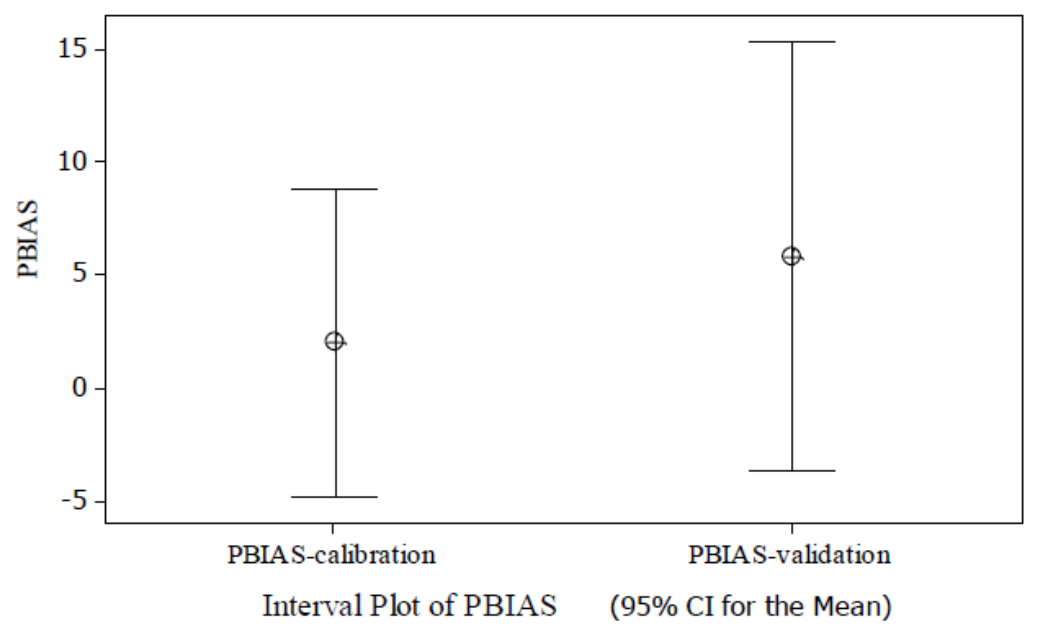

Fig. 4. Daily model statistics at 9 USGS gage stations during model calibration (a) and validation (b) period. The lower panel shows the interval plot of percentage bias (PBIAS) error for calibration and validation

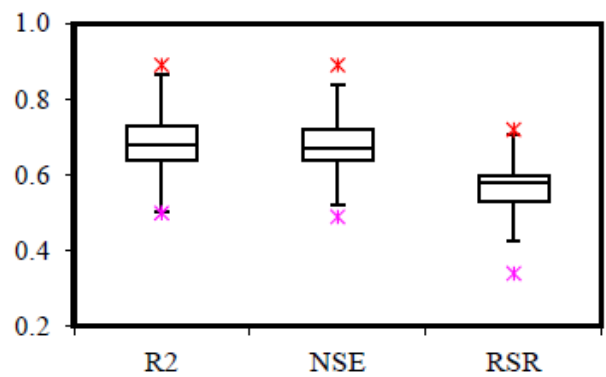

(a)

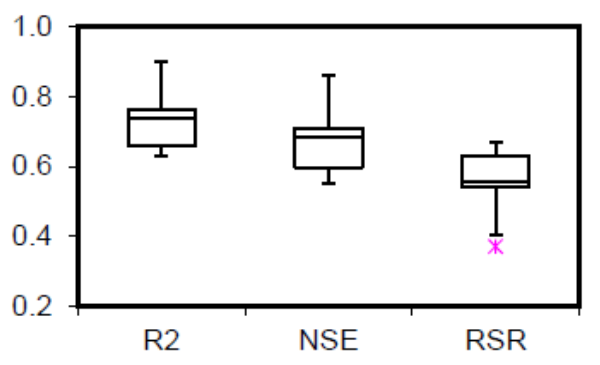

(b) 


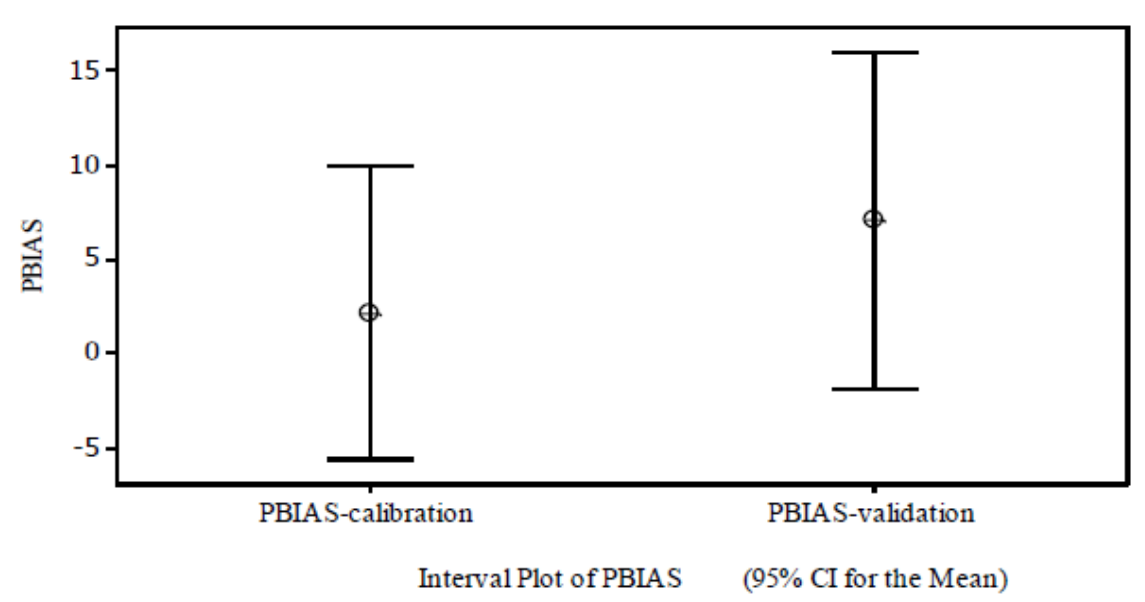

Fig. 5. Monthly model statistics at 9 USGS gage stations during model calibration (a) and validation (b) period. The lower panel shows the interval plot of percentage bias (PBIAS) error for calibration and validation

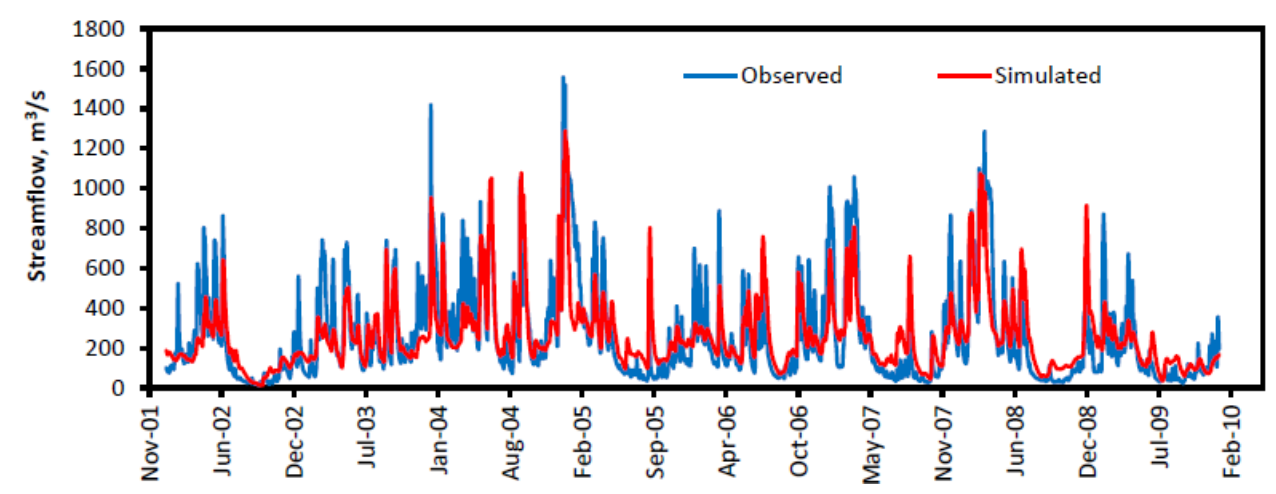

Fig. 6. Daily streamflow calibration at watershed outlet (USGS gage 03150000)

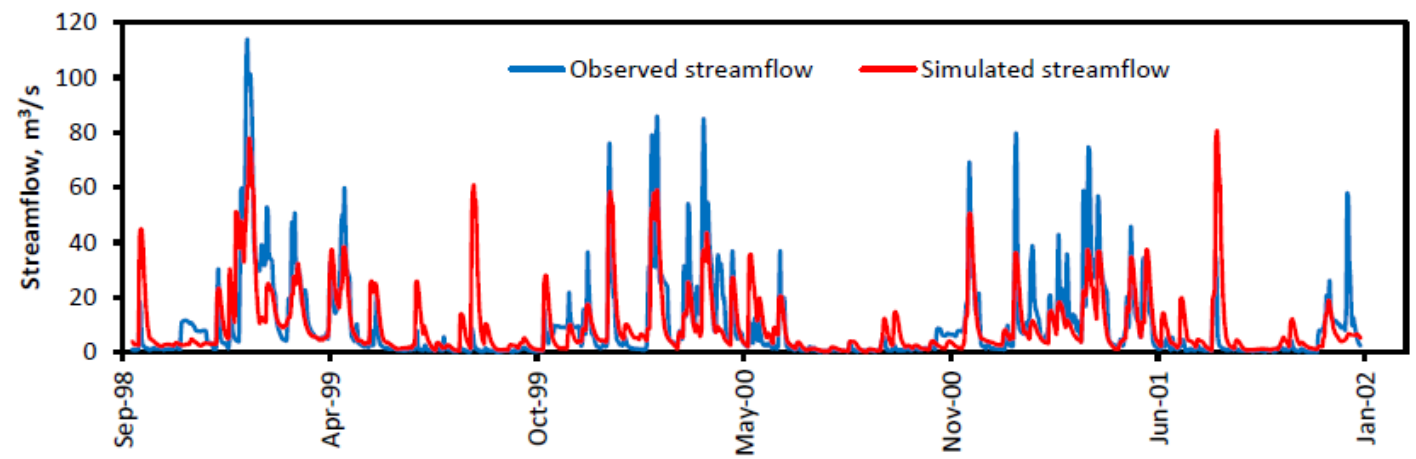

Fig. 7. Daily streamflow validation at the USGS gage 03142000 (next to watershed outlet as outlet did not have long term record beyond year 2000)

\section{Impact Due to Fracking}

Our analysis depicted the consistent increasing drilling trend in Muskingum watershed. Since it is essential to maintain environmental low flows for sustainable water availability including downstream right, aquatic habitat and others, low flows for current fracking period was evaluated considering water withdrawal over the watershed. The result showed that the water withdrawal during low flow period (August through November) was about $43 \%$ of the total water withdrawal (Fig. 8). Model was used to quantify the effect of these withdrawals over this period. 32 subbasins were affected by fracking, which had drainage 
area less than $140 \mathrm{~km}^{2}$. Analysis was categorized in yearly and monthly periods; mean for current year, dry and high flow season were calculated, separately. Results revealed that the greater alterations were found in seasonal mean (high flow) than the yearly mean flow. However, these changes were only detected in 5 subbasins out of 32 subbasins, with less than 1.5 percentage difference, indicating that impact is not significant in yearly and seasonal mean flow (high flow season) in the streams. Also, dry flow seasonal mean showed significant variances only in two subbasins (5.9 and $20.16 \%$ ) with no significant changes on the remaining subbasins. However, the difference was noticed when the monthly analysis was performed. Minimum 6 percentage difference was observed while comparing current and baseline scenario. However, this difference was relatively more when hydraulic fracking effect is analyzed over the 7 days minimum monthly low flows. Out of 32 subbasins, 8 subbasins with less than $118 \mathrm{~km}^{2}$ drainage area revealed more than $5 \%$ difference in 7 days minimum monthly flow while comparing baseline (without hydraulic fracking) and current scenarios (Fig. 9). Figure 10 presented both the monthly mean and seven days monthly minimum flows in 8 subbasins. Interestingly, major impacts were observed in first order streams. The subbasins which showed the differences in 7 days low flows and monthly minimum flows are displayed in Fig. 11. In general, our analysis shows lesser impact on the annual and seasonal water balance but indicates that the effect might be critical over low flow such as 7 day minimum flow, especially on lower order of streams.

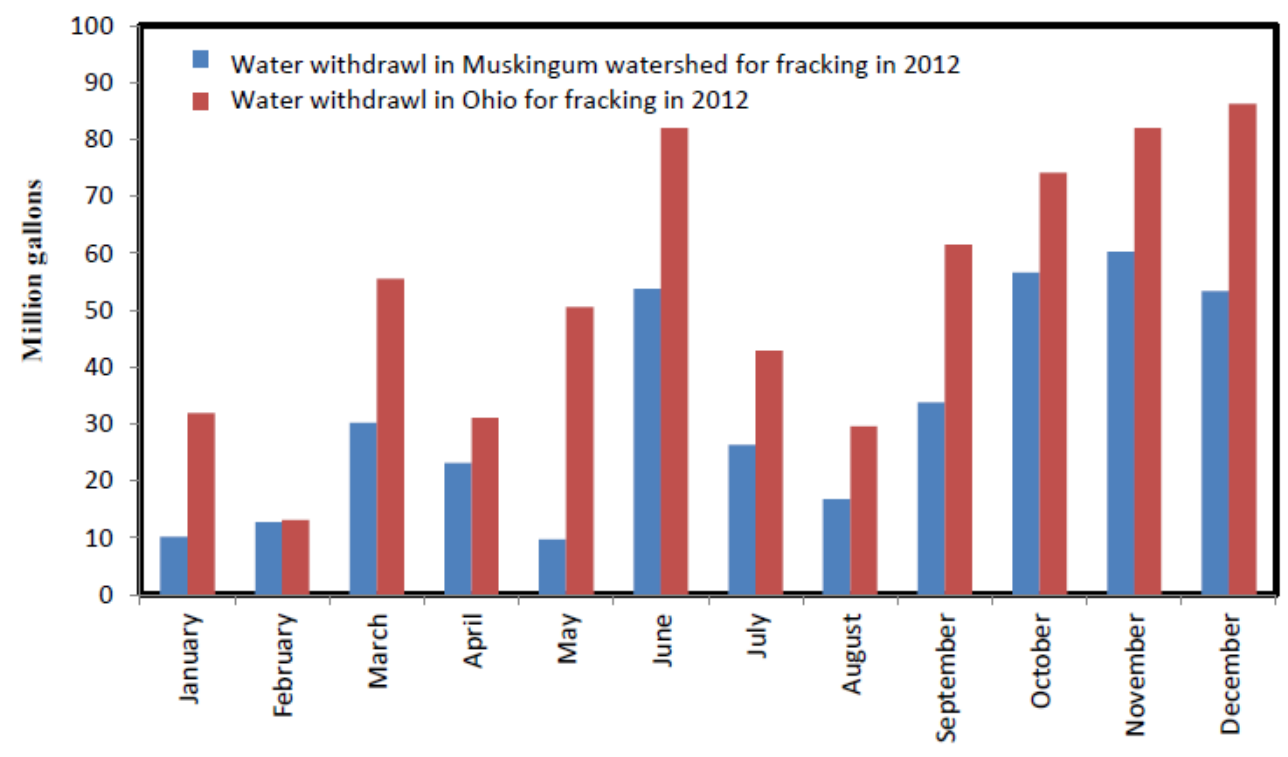

Fig. 8. Water withdrawals for hydraulic fracturing in 2012 in Muskingum watershed and Ohio, respectively

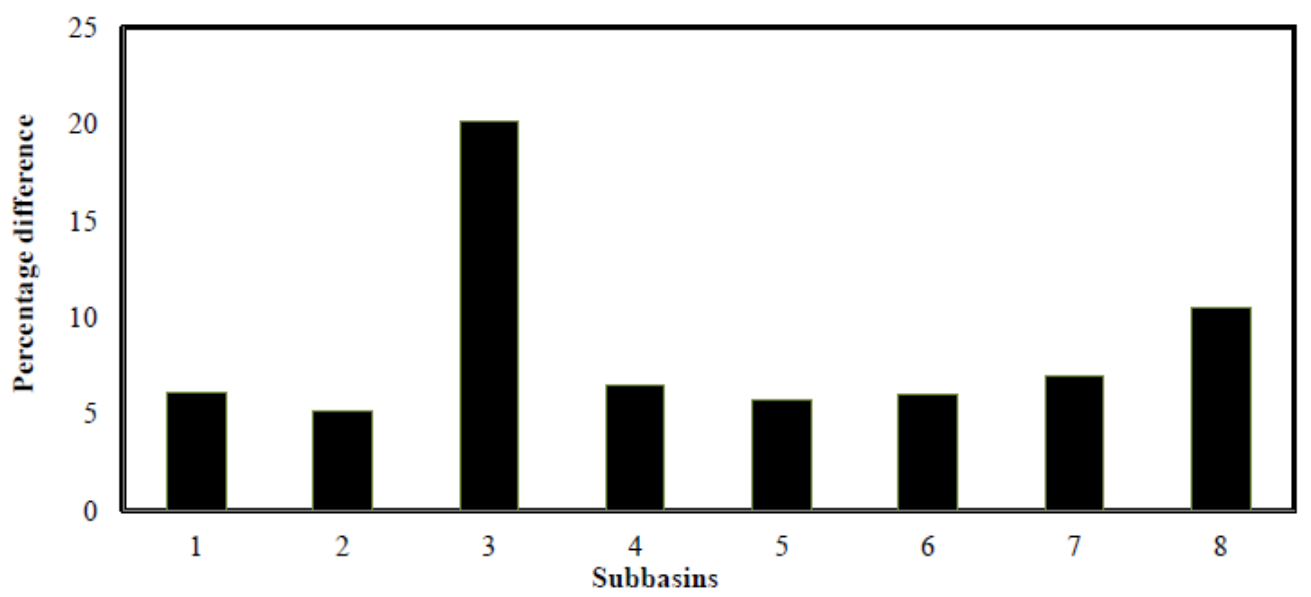

Fig. 9. Percentage difference in 7 day minimum flow between baseline and current fracking scenario on 8 affected subbasins during current period 


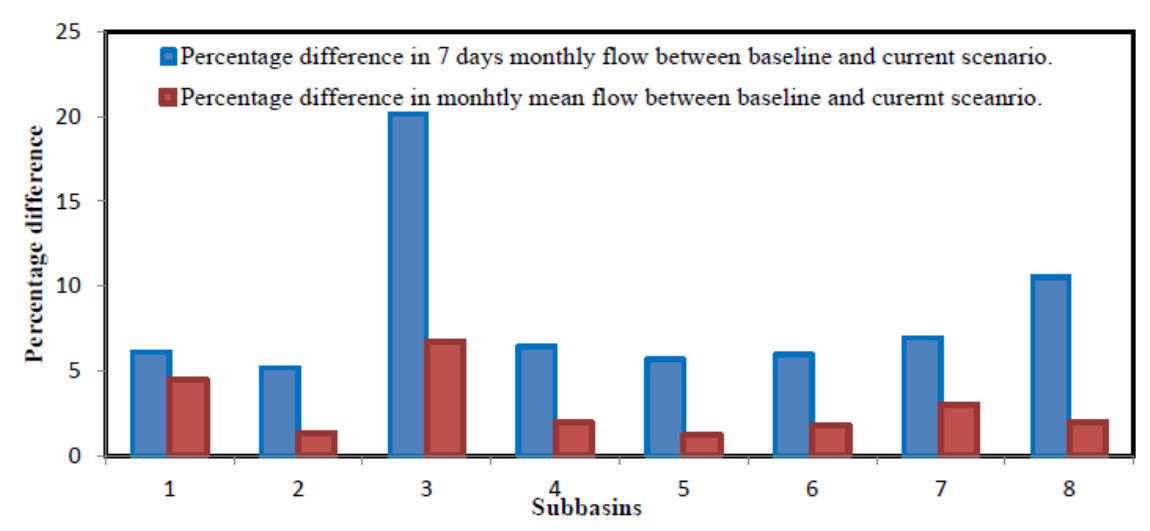

Fig. 10. Percentage differences of 7 day minimum monthly flow and monthly mean between baseline and current fracking scenario on 8 affected subbasins

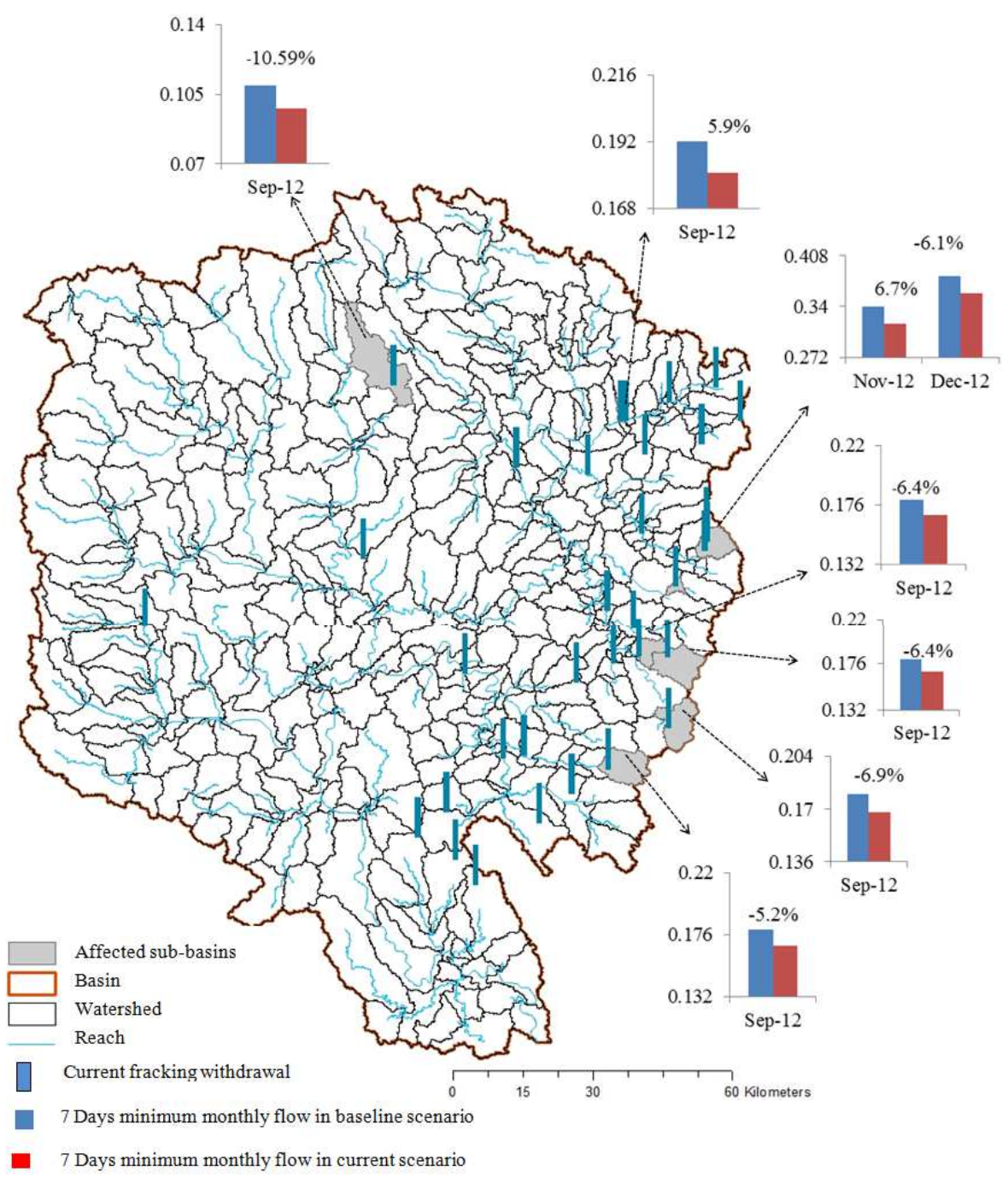

Fig. 11. Impact of current fracking scenario on 7 day minimum monthly flow in Muskingum watershed

The case study revealed that the impact of water withdrawal is significant during low flow period and this effect is significant particularly in small order streams.
Similarly, baseflow variation during low flow period suggests that ground water is dominant component for the discharge into most of rivers during this period. 
However, the result might be different in various subbasins in accordance with the existing water use and point source discharge of that particular subbasin.

\section{Modeling Challenges for Hydraulic Fracking Study}

While we selected SWAT models for this study, the issues and challenges associated with SWAT model application will be similar to the issues associated with abovementioned models discussed in this article if the users select other models. Therefore, we will present the challenges and difficulties in model application in a generic term, irrespective of the type of model chosen.

\section{Calibration and Validation Issues}

The lacks of water withdrawal data for various purposes such as irrigation, water supply and for various other purposes are neither well recorded nor easily available. On the other hand, lack of required datasets for long term calibration and validation is another issue to evaluate the appropriate selection of watershed models in order to quantify the effect of hydraulic fracking on water resources management. The quantity of water needed for hydraulic fracking also varies from case to case basis and there is no specific record of the water withdrawal information for hydraulic fracking as it relies in the geological condition, depth, lateral length, type of rock and other physical conditions of the sites. The water used for fracking eventually ends up in underground disposal wells and hence removed from the hydrologic cycle. The water used for fracking also primarily used from various sources including municipal water systems, streams, reservoirs, private ponds etc. The exact water withdrawal location is always uncertain and raises several questions for the reliability of the modeling results. In addition, certain amount of water will be disposed to the streams/rivers after treatment of drilled wastewater. The amount of water disposed also varies from location to location; exact data are needed to make a reliable prediction using models. Therefore, modeler needs to make an assumption due to lack of exact disposed water from each site. Also, the water disposed could be surface water or in some case ground water. More importantly, the representation of exact timing of water withdrawal and disposal within a year in a simulation model is another challenging issue because company can withdraw water any time after receiving the license from concerned federal agencies (in this case, ODNR). Similarly, modeler's also needs to rely on the assumption of exact location of well sites because companies may drill at any convenient location of the watersheds. Another limitation is that modeler is always uncertain about the possible changes in population and land use change practice in near future while developing future scenarios of water acquisition due to hydraulic fracking.

\section{Flowback and Produced Water Effect}

The disposed flow may have pronounced effect on water quality at certain sections of the stream but not for the entire streams. In future, detail databased should be prepared and existing models should be modified to incorporate the possible consequences of accidental discharge, leak and spills of flowback and produced water.

\section{Scaling Issues}

The impact of fracking may vary both at temporal and spatial scales and intensive study is needed for any generalization of the study. For instance, the impact of withdrawal may have different range of impact on daily water availability and monthly water availability. Furthermore, the spatial distribution of the fracking locations within the watershed also affects the net amount of water within the tributaries. That is, if the frakings wells are concentrated near to the particular tributaries, it may have significant impact for those particular tributaries; however, it may not have substantial effect far downstream of the stream or at the watershed outlet. Therefore, modeler's need to acquire appropriate information of fracking wells and their spatial locations. The scale of fracking that affect water resources sustainability is still a matter of further investigation and could be an interesting topics for future research.

\section{Policy Consequences and Future Outlook}

The oil and gas production may result significant impact on water resources and environmental sustainability leading to the demand on policy changes in future. For example, the hydrological and biological conditions of the watershed will be greatly affected due to fracking; therefore, water withdrawal for fracking should be incorporated in NPDES permitting and TMDL development of the affected watershed in future. The hydraulic fracking may also change the land use practices, agricultural practices and locations of best management practices to be adopted within the watershed in future.

Proper development of complete database of hydraulic fracking information is needed for the use of current watershed models to deal with the complex interactions of hydraulic fracking with watershed characteristics. For this, stakeholder participation should be encouraged and information should be shared through the active stakeholders' consultation. More specifically, the complete database of hydraulic fracking is needed in future before analyzing impact of hydraulic fracking on water resources. 
The US government should devise future policies for the environmental safeguard and water resources sustainability against fracking. Decision-support systems will be useful to provide policy level solutions to the active stakeholders related with hydraulic fracking and its impact on water resources. Therefore, hydrologic models should be advanced to incorporate hydraulic fracking in future. While the site specific conditions may be different from location to location, generic effect of fracking on water resources can be extrapolated using such simulation study.

\section{Conclusion}

In this study, the state of art of existing watershed models has been presented to conduct simulation study due to water withdrawal associated with hydraulic fracking. The capabilities of widely adopted 7 watershed models (HSPF, MIKESHE, SWAT, WARMF, APEX, WAM and HEC-HMS) to incorporate fracking was systematically reviewed and documented with proper citation. Our study does not warrant the abovementioned models only to incorporate fracking for simulation study as there are numerous watershed models available. While most of the watershed models have an option of incorporating hydraulic fracking process, the SWAT model was selected among the various candidate watershed models. A separate case study was presented to demonstrate the potential application of SWAT model for the assessment of hydraulic fracking and its impact on the water resources, especially on low flow period.

Simulated flows in ungauged locations under the current fracking situation were used to assess the potential impact of water withdrawal for hydraulic fracking on water resources both at spatial and temporal scales. The study suggested that the impact was more significant during low flow than average flow or peak flow period. Seven days minimum flows showed some variation when compared with the 7 days minimum flow without fracking indicating that proper regulations of drilling activities are needed during the low flow period. Such flow alteration may bring the daily flow below the environmental flow limits, which may eventually threaten the water resources sustainability.

Even though simulation studies are always associated with a certain degree of uncertainty, this study concludes that SWAT could be a potential tool for the hydrologic assessment and water quality evaluations in the future under different scenarios of hydraulic fracking. This study also concludes that fracking has a modest effect on seven day low flows; therefore, water quality impacts due to hydraulic fracking will be an interesting research topic for the future. Overall, this research summarizes following issues which might be helpful to improve hydrologic assessments and management strategies in the future:

- Watershed models can be utilized to evaluate several water acquisition scenarios associated with hydraulic fracking both at spatial and temporal scales with some modification, if any

- Lack of sufficient data and information for hydraulic fracking study at various spatial locations is one of the major limitations

- Complete database regarding the information of exact withdrawal and water disposal location is needed in future

- Coupling of groundwater and surface water modeling process is needed in future for thorough investigation

- Hydraulic fracking may have nominal impact on water quantity in this region, but the water quality impact due to flow back and produced untreated water could be significant

\section{Acknowledgement}

Authors would like to acknowledge for the small grant support from the United State Geological Survey/ National Institutes for Water Resources (USGS/NIWR) through the Ohio Water Resources Centre of the Ohio State University for this research work.

\section{Author's Contributions}

Suresh Sharma: Wrote the article as a leading author and helped in analysis.

Aashish Shrestha: Analyzed and helped in writing.

Colleen E. McLean: Provided fracking information, Involved in research.

Scott C. Martin: Helped in editing and provided feedback.

\section{Ethics}

The article is original and contains unpublished material.

\section{References}

Abbaspour, K.C., M.A. Sonnleitner and R. Schulin, 1999. Uncertainty in estimation of soil hydraulic parameters by inverse modeling: Example lysimeter experiments. Soil Sci. Society Am. J., 63: 501-509. DOI: $10.2136 /$ sssaj 1999.03615995006300030012x

Abbaspour, K.C., 2007. User manual for SWAT-CUP, SWAT calibration and uncertainty analysis programs. Swiss Federal Institute of Aquatic Science and Technology, Eawag, Duebendorf, Switzerland. 
Abbaspour, K.C., J. Yang, I. Maximov, R. Siber and K. Bogner et al., 2007. Modelling hydrology and water quality in the pre-alpine/alpine Thur watershed using SWAT. J. Hydrol., 333: 413-430.

DOI: $10.1016 /$ j.jhydrol.2006.09.014

Allen, R.G., 1986. A Penman for all seasons. J. Irrigation Drainage Eng., 112: 348-368.

DOI: 10.1061/(ASCE)0733-9437(1986)112:4(348)

Arabi, M., J.R. Frankenberger, B.A. Engel and J.G. Arnold, 2008. Representation of agricultural conservation practices with SWAT. Hydrol. Processes, 22: 3042-3055. DOI: 10.1002/hyp.6890

Arnold, J.G., R. Srinivasan, R.S. Muttiah and J.R. Williams, 1998. Large area hydrologic modeling and assessment part I: Model development1. J. Am. Water Resources Associat., 34: 73-89. DOI: $10.1111 / \mathrm{j} .1752-1688.1998 . t b 05961 . x$

Bicknell, B.R., J.C. Imhoff, J.L. Kittle Jr., A.S. Donigian Jr. and R.C. Johanson, 1996. Hydrological Simulation Program-Fortran User's Manual for Release 11. 1st Edn., USEPA, Washington, DC.

Borah, D.K. and M. Bera, 2003. Watershed-scale hydrologic and nonpoint-source pollution models: Review of mathematical bases. Trans. ASAE, 46: 1553-1566. DOI: $10.13031 / 2013.15644$

Bottcher, A.B., B.J. Whiteley, A.I. James and J.H. Hiscock, 2012. Watershed Assessment Model (WAM): Model use, calibration and validation. Trans. ASABE, 55: 1367-1383. DOI: $10.13031 / 2013.42248$

Douglas-Mankin, K.R., R. Srinivasan and J.G. Arnold, 2010. Soil and Water Assessment Tool (SWAT) model: Current developments and applications. Trans. ASABE, 53I: 1423-1431. DOI: 10.13031/2013.34915

Faramarzi, M., K.C. Abbaspour, R. Schulin and H. Yang, 2009. Modelling blue and green water resources availability in Iran. Hydrol. Processes, 23: 486-501. DOI: 10.1002/hyp.7160

El-Nasr, A.A., J.G. Arnold, J. Feyen and J. Berlamont, 2005. Modelling the hydrology of a catchment using a distributed and a semi-distributed model. Hydrol. Processes, 19: 573-587. DOI: 10.1002/hyp.5610

Gassman, P.W., M.R. Reyes, C.H. Green and J.G. Arnold, 2007. The soil and water assessment tool: Historical development, applications and future research directions. Center for Agricultural and Rural Development, Iowa State University.

Gassman, P.W., J.G. Arnold, R. Srinivasan, M. Reyes and F. Huang et al., 2010. The worldwide use of the SWAT Model: Technological drivers, networking impacts and simulation trends. Proceedings of the International SWAT Conference, (SWAT' 10), Seoul, South Korea, pp: 129-137.

Gassman, P.W., A.M. Sadeghi and R. Srinivasan, 2014. Applications of the SWAT model special section: Overview and insights. J. Environ. Q., 43: 1-8. DOI: $10.2134 /$ jeq2013.11.0466
Golmohammadi, G., S. Prasher, A. Madani and R. Rudra, 2014. Evaluating three hydrological distributed watershed models: MIKE-SHE, APEX, SWAT. Hydrology, 1: 20-39.

Hargreaves, G.H. and Z.A. Samani, 1985. Estimating potential evapotranspiration. Tech. Note. J. Trrig. Drain. Eng., 108: 225-230.

Im, S., K. Brannan, S. Mostaghimi and J. Cho, 2003. A comparison of SWAT and HSPF models for simulating hydrologic and water quality responses from an urbanizing watershed. In An ASAE Meeting Presentation, The Society for Engineering in agricultural, food and biological systems, ASAE Riviera Hotel and Convention Center, USA.

IOGCC, 2010. Resolution on hydraulic fracturing 09.011. Interstate Oil and Gas Compact Commission.

Jackson, R.B., A. Vengosh, T.H. Darrah, N.R. Warner and A. Down et al., 2013. Increased stray gas abundance in a subset of drinking water wells near Marcellus shale gas extraction. Proc. Nat. Acad. Sci. 110: 11250-11255. DOI: 10.1073/pnas. 1221635110

Jha, M.K., 2011. Evaluating hydrologic response of an agricultural watershed for watershed analysis. Water, 3: 604-617. DOI: 10.3390/w3020604

Monteith, J.L., 1965. Evaporation and environment. Symp. Soc. Experim. Biol., 19: 205-224. PMID: 5321565

Moriasi, D.N., J.G. Arnold, M.W. Van Liew, R.L. Bingner and R.D. Harmel et al., 2007. Model evaluation guidelines for systematic quantification of accuracy in watershed simulations. Trans. ASABE, 50: 885-900. DOI: 10.13031/2013.23153

Nash, J.E. and J.V. Sutcliffe, 1970. River flow forecasting through conceptual models Part I: A discussion of principles. J. Hydrol., 10: 282-290. DOI: 10.1016/0022-1694(70)90255-6

OEPA, 2012. Ohio's regulations: A guide for operators drilling in the marcellus and Utica Shales. Ohio Environmental Protection Agency, Ohio.

Priestley, C.H.B. and R.J. Taylor, 1972. On the assessment of surface heat flux and evaporation using large-scale parameters. Mon. Weather Rev., 100: $\quad 81-82$. DOI: $10.1175 / 1520$ 0493(1972) 100<0081:OTAOSH >2.3.CO;2

Rahman, M., T. Bolisetti and R. Balachandar, 2010. Effect of climate change on low-flow conditions in the Ruscom river watershed, Ontario. Trans. ASABE, 53: 1521-1532. DOI: 10.13031/2013.34904

Saleh, A. and B. Du, 2004. Evaluation of SWAT and HSPF within BASINS program for the upper north Bosque river watershed in central Texas. Trans. ASAE, 47: 1039-1049. DOI: 10.13031/2013.16577

Schuol, J., K.C. Abbaspour, R. Srinivasan and H. Yang, 2008. Estimation of freshwater availability in the West African sub-continent using the SWAT hydrologic model. J. Hydrol., 352: 30-49.

DOI: $10.1016 /$ j.jhydrol.2007.12.025 
Singh, J., H.V. Knapp, J.G. Arnold and M. Demissie, 2005. Hydrological modeling of the Iroquois river watershed using HSPF and SWAT. J. Am. Water Resour. Assoc., 41: 343-360. DOI: $10.1111 /$ j.1752-1688.2005.tb03740.x

Stehr, A., P. Debels, F. Romero and H. Alcayaga, 2008. Hydrological modelling with SWAT under conditions of limited data availability: Evaluation of results from a Chilean case study. J. Hydrol. Sci., 53: 588-601. DOI: 10.1623/hysj.53.3.588

USDA, S., 1972. Soil survey laboratory methods and procedures for collecting soil samples. Soil survey investigations Rep, 1.

USDA, 1991. State Soil Geographic (STATSGO) Database: Data Use Information. Miscellaneous United States Department of Agriculture.

USEIA, 2011. International energy outlook 2011, coal, natural gas, electricity. Energy information administration, Independent analysis and statistics.

USEPA, 2012. Study of the potential impacts of hydraulic fracturing on drinking water resources: Progress report. USA Environmental Protection Agency, USA.
Van Liew, M.W., J.G. Arnold and J.D. Garbrecht, 2003. Hydrologic simulation on agricultural watersheds: Choosing between two models. Trans. ASAE, 46: 1539-1551. DOI: $10.13031 / 2013.15643$

Verma, A.K., M.K. Jha and R.K. Mahana, 2010. Evaluation of HEC-HMS and WEPP for simulating watershed runoff using remote sensing and geographical information system. Paddy Water Environ., 8: 131-144. DOI: 10.1007/s10333-009-0192-8

Xie, H. and Y. Lian, 2013. Uncertainty-based evaluation and comparison of SWAT and HSPF applications to the Illinois River Basin. J. Hydrol., 481: 119-131. DOI: 10.1016/j.jhydrol.2012.12.027

Yang, J., P. Reichert, K.C. Abbaspour, J. Xia and H. Yang, 2008. Comparing uncertainty analysis techniques for a SWAT application to the Chaohe Basin in China. J. Hydrol., 358: 1-23. DOI: 10.1016/j.jhydrol.2008.05.012 